\title{
THE ECONOMICS OF WAGE-DISPUTE SETTLEMENT
}

\author{
John T. DunLop*
}

"The science of political economy is essentially practical, and applicable to the common business of human life. There are few branches of human knowledge where false views may do more harm, or just views more good." Ever since Malthus penned this high estimate of his chosen discipline there have been doubters and blasphemers. ${ }^{2}$ While there have been notable advances in quantitative eco nomics, the application of economic theory or principles to particular situations is a rudimentary craft. Serious economists have rarely been attracted to a practice, except in such a period as that of the recent war.

While the professional economist has tended to avoid the market place, participants in the world of affairs have borrowed liberally of economic ideas to rationalize their positions. As a consequence, never were economic clichés and slogans so widespread and so frequently utilized in public argument. It is doubtul if there is any greater real understanding of problems; there may be less. Mill's judgment of his day probably fits our own: "I do not perceive that in the mental training which has been received by the immense majority of the reading and thinking part of my countrymen ... there is anything likely to render them much less accessible to the influence of imposture and charlatanry than there ever was."

The debate over wage rates in the public press and in proceedings between management and labor organizations has popularized economic analysis. There has come into use a limited number of clichés or standard arguments which are employed by the side that regards them as most effective at the time in winning the case. Illustrative of these phrases are "comparable wages," "productivity," "cost of living," and "ability to pay." These slogans are not the distinctive trademark of any one side. Either party may use one of these arguments today and repudiate it tomorrow as a factor in wage determination under a different set of circumstances. Current wage argument is a "dreadful pudder o'er our heads."

- A.B. 1935, Ph.D. 1939, University of California. Associate Professor of Economics and member of the Faculty, Littauer School of Public Administration, Harvard University. Formerly Consultant, Office of Economic Stabilization and Office of War Mobilization and Reconversion; Public Member, Wage Adjustment Board for the Building and Construction Industry, and Vice-Chairman, War Labor Board, Region I. Author, Wage Determination under Trade Unions (I944). Contributor to periodicals.

${ }^{1}$ T. R. Malthus, The Principles of Political Economy (London School of Economics and Political Science Reprint, 1936) 9.

* For a recent discussion, see Elton Mayo, The Social Problems of an Industrial Civilization (1945) $34-56$,

- John Stuart Mill, The Spirit of the Age (Chicago University Press 1942) 10-I1. 
The interest in arguments and slogans in wage negotiations has increased spectacularly in recent years with the growth of private arbitration; the participation of government in wage setting through the machinery of the Railway Labor Act, the wartime experience under the National War Labor Board, and the postwar vogue of factfinding boards. The employment by management and labor organizations of technicians, such as lawyers, economists, statisticians, actuaries, industrial engineers, and publicists, who produce voluminous briefs and endless statistical appendices, has given wide currency to such wage-determining principles or slogans.

The subject of this paper might be developed along several entirely different lines. The emphasis might be placed on developing an explanation for wage determination under collective bargaining. ${ }^{4}$ It has seemed more in keeping with the spirit of this symposium rather to appraise carefully and rigorously some of the more prominent arguments and slogans used in wage discussions. Much of the discussion will be devoted to exploring problems that arise in giving meaning to these standards and in translating them into definitely measurable guides to decisions in particular situations. The problems will be found to be stubborn and not always tractable. This emphasis is not, however, fundamentally defeatist with respect to the contribution of economics to wage dispute settlement. The identification of problems is the beginning of economic wisdom.

The orientation of the following pages is primarily on standards seriously proposed in particular cases. The discussion of the appropriate general level of wage rates for the economy as a whole has resort normally to a different group of criteria. The first four sections which follow organize the problems associated with the application of four standards for particular cases: "comparable wages," "productivity," "cost of living," and "ability to pay." A following section summarizes the fundamental problems raised by an examination of these standards. A brief sixth section is devoted to the criteria used in discussing the general level of wage rates. The final section appraises the distinctive contribution which the economist may make to the settlement of wage disputes.

\section{Comparable Wage Rates}

No argument is employed more frequently in wage discussions than that wage rates in one bargaining unit should be equalized with, or related by a particular differential to, wage rates in other "comparable" bargaining units. While other arguments are more decisive in the "key" wage bargains in basic industries affecting the general level of wage rates, the appeal to comparable rates is frequently employed in transmitting the impact of these critical decisions throughout the rest of the wage structure. The resort to this standard is also frequently the basis for the numerous changes in differentials that are made among occupations, plants, and industries each year.

\footnotetext{
- See John T. Dunlop, Wage Determination Under Trade Untons (ig44) chaps. 2-6.
} 
The principle that wage rates in one bargaining unit should be adjusted to the level of wage rates in comparable plants has an alluring simplicity. The economist indicates that in equilibrium the same wage rate will be paid in "a market" for a specified type of labor service. The slogan of "equal pay for equal work" commands wide support. However, for reasons which will now be surveyed, the illusion of simplicity vanishes in the attempt to give meaning to the concept of "comparable" wage rates in any particular dispute situation.

(I) The content of job classifications designated by the same job title varies widely among different employers. The range of duties assigned to a single worker has not been as standardized among plants as is widely assumed. The varying ages and types of equipment, the differing scales of operation between large and small plants, and the different techniques of various managers are factors making for different job contents among firms producing roughly similar goods. Various arrangements may be made, for instance, in machine operations for the cleaning, oiling and greasing of equipment. The flow of materials to a machine and the handling of processed parts and waste products permit different plans of organization. The extent of supervision and inspection in a job may also vary widely from one plant to another.

For instance, a study of the distribution of spinning-room duties in forty-seven cotton textile firms ${ }^{5}$ divided the work of five customary job classifications-spinner, cleaner, oiler, sweeper and doffer-into twenty-five separate operations. No two of the mills divided these operations in the same way among the job classifications. Except for the operations of "creeling" and "piecing up," performed by the spinner in all cases, no operation was assigned to the same job classification in all mills. The total duties of the spinner varied from these two operations in one mill to as many as ten in another. The comparison of the wage rates by job classification among these various cotton textile mills under these circumstances requires temerity.

At the request of the United States Conciliation Service in particular disputes, the Bureau of Labor Statistics has made a number of surveys of occupational wage rates in comparable establishments. The most recent of these studies examines the differences between duties among the various firms studied. The ordinary occupational wage-rate survey of the Bureau of Labor Statistics ${ }^{6}$ starts with a single description for a "standardized" job classification. As long as a common core of duties is performed, the wage-rate data are collected from a particular firm and compared with rates from other firms. The newer special studies for the Conciliation Service recognize that there are wide variations in the actual content of jobs which roughly fit the same job description. These inquiries uniformly reveal the same range of diversity in job content illustrated by the distribution of spinning-room duties.

(2) Comparability in wage rates is impaired by variations in the method of wage

- Presented as an exhibit before the National War Labor Board in the cotton textile cases decided Feb. 20, 1945, 21 WAR LAB. REP. 793.

- Wartime Wage Movements and Urban Wage-Rate Changes (1944) 6I Mo. LAB. Rev. 684-704. 
payment. Some workers and job classifications are remunerated on an hourly rate basis, others are on individual piece-rates or incentive rates, while still others are paid on group incentive plans. The content of job classifications may be identical, but the amount of services performed and purchased will ordinarily vary with the method of wage payment. Commission methods of wage payment add the further complexity of variations in the price structures of the products being sold. Among incentive systems there are substantial differences in the definitions of the "standard performance" and the extent of "incentive pull" for additional output. The provisions regarding minimum guarantees, including rates for machine breakdowns, poor materials, etc., and the method of calculating these guarantees-by day, by week, or other period-affect the meaning of inter-plant comparisons of wages.

(3) The influence of regularity of employment upon wage rates must be assessed in defining comparable wages. The level of rates for maintenance occupations with steady employment is frequently, although not always, below the rates for the same crafts engaged in seasonal construction work. While there are some important differences in job content, the regularity of employment is usually indicated as the principal reason for this difference. The difference between wages of mechanics in the repair shops of taxicab and truck companies and those of their fellow-craftsmen in commercial garages also reflects the factor of regularity of employment, although - job content and methods of wage payment also differ. In fact, wage rates in "cap: tive" departments of a company with relatively steady work opportunities are typically below those of the "outside" or "contract" firm with greater fluctuations in available work. Comparison of two groups of employees for wage-setting purposes will be complicated by the task of assessing the extent to which wage rates reflect differences in the regularity of employment.

(4) The terms and conditions of employment typically include not only the occupational rate but also other "money" conditions such as shift premiums, vacations and holidays with pay, sick leave, pensions, social and health insurance, paid lunch periods, Christmas bonuses, etc., to mention the more prominent terms. The total contract of employment involves many other items that are less immediately "money" terms, such as union recognition, seniority, management rights and grievance machinery, and arbitration. In the bargaining process there is frequently give and take among the "money" terms. There is likely to be substitution among basic rate adjustments and shift premiums, vacations, and health insurance plans. There may even be important trades between the "money" items and other provisions of a contract. Comparison of wage rates under these circumstances may become particularly tenous.

(5) The geographical implications of "comparable wages" can be most perplexing. The concept of a "labor market" has no direct correspondence in geography.

\footnotetext{
'The Bureau of Labor Statistics now reports much data of this kind in connection with wage rave surveys on form OWR-17.
} 
Specifying the labor market in accordance with the cost of transportation or the knowledge of job and wage opportunities does not yield precise results. The inclusion of suburbs and satellite communities can be as difficult as the grouping of larger towns and cities. The War Labor Board for the Boston Region was plagued throughout the war.with the question whether to include Torrington ( 16 miles away) in the Waterbury, Connecticut labor market for metal trades occupations. The areas of uniformity of wage rates may vary widely among occupations even in the same industry: compare laborers and iron workers in the construction industry. The areas of uniformity have in general spread in recent years, although uniformity appears to be greater in periods of high employment than in loose labor markets. If the standard of comparable wages is to be employed we cannot escape the difficult task of defining the geographical limits of the appropriate labor market.

(6) The complications of "comparable" wage determination developed so far in this section relate to labor-market difficulties. They derive from relating the exact work performed by the wage earners in different bargaining units or from the influence of what are essentially labor-market influences on wage rates. There is another group of problems which must be faced in giving meaning to "comparable wage rates." These have their roots in the product market, or, more precisely, in the divergent competitive positions of the firms employing the wage earners.

Business enterprises are ordinarily regarded as clustering into industries, segments, or smaller groups among which product competition is relatively closer than with firms outside the group. But every business, outside the case of a few perfectly competitive markets, has its specialized market and clientele. The grouping of firms according to similarity of product-market conditions is a convention always subject to further subdivision. The definition of these clusters of "comparable" firms is probably as difficult as any issue in applying the wage standard discussed in this section.

The local transit industry includes primary and feeder-line companies; hotels are classified into first-line and several other classes; bakeries may be divided into largescale operators and specialty shops. Are the larger or smaller units appropriate for comparison? The trucking firms in an area may be subdivided into over-the-road and local trucking enterprises. The latter may be classified in turn into product groups-oil, coal, grocery, department store, express, etc. Any one of these groups, such as oil, in turn could be further subdivided into: national distributors, local companies, home delivery, industrial uses, etc. While many of these groupings are associated with important differences in job content (type of equipment) and method of wage payment, competitive conditions among these various groups no doubt vary widely. The important question is to determine when these differences in competitive conditions are so significant as to warrant a separate wage determination regardless of labor-market influences. 
The problem may be posed even more sharply by an instance in which labormarket influences are relatively more uniform than in the trucking case. An engine lathe operator may work for companies ordinarily classified in such groups as electrical machinery, textile machinery, machine tools, and shoe machinery. In determining the "comparable" wage rates, what grouping of firms should be selected?

There can be little doubt that wage rates do in fact vary by virtue of the influence of divergent product-market conditions. Maintenance workers, for instance, have rates that vary substantially through the range of industries even where job content is quite similar. The choice of groupings among firms presents the most difficult of problems.

The foregoing discussion of six groups of problems is adequate to divest the slogan or standard of "comparable wages" of any alluring simplicity. It is doubtful if there are any royal answers to these problems in principle or in measurement. The difficulties arising from the product market can be mitigated, however, if agreement is secured from the parties as to a list of comparable firms. This device has been frequently used by mediators.

\section{Productivity}

No argument is used with more conviction or sophistication than that wages should vary with changes in productivity. In the mid-Twenties the American Federation of Labor Convention adopted the policy that wage earners should share in rising productivity in the form of wage-rate increases. In recent days management, editorial writers, ${ }^{8}$ economists, and some labor leaders have been preaching that increased productivity alone provides the basis for wage increases. These views have normally been associated with the conviction that wage rates have already outstripped productivity. As part of the mores or folklore of an industrial community there may be little objection to the slogan of productivity as a basis for increases in the general level of wage rates in the long run. As a guide or a rule of thumb in any particular negotiation, the principle has grave difficulties which may be briefly summarized.

(I) The rate of change in productivity in our economic system varies widely among the component segments. Within an industry the rate is normally quite different among firms. Even within a firm or plant the rate varies among departments, machines, and operations. The wage structure of a particular plant or department, if it were geared absolutely to changes in productivity, would soon become intolerable. Employees in continuous strip mills and on tin plate operations in the steel industry, for instance, would have had enormous wage increases in the past ten years in comparison with employees in other sectors of the industry. Under such circumstances the wage structure would bear very little relationship to skill, experience, or other factors typically taken into account in settling rate structures. Nor would

see HenRy HazLitT, Economics in ONe Lesson (1946) c: XIX. 
the wage structure bear any relationship to wages paid for comparable operations in other industries in steel centers. The exclusive adoption of the principle of adjusting wage structures according to changes in productivity would result within a very short time in an utterly chaotic wage structure within a single plant or industry.

In the same way, the adjustment of wage levels among industries exclusively by reference to this slogan would distort the wage structure of the country. Industries in which productivity increased rapidly would experience large wage increases, while in others in which productivity did not increase or actually declined (especially in extractive industries) wage rates would remain relatively unchanged. Either as a matter of allocation of resources or as a means to the maintenance of industrial peace, the absolute adoption of such a principle for determining the structure of wages among industries would be a catastrophe.

All this is not to say that changes in productivity do not have effects upon the structure of wages within plants or among industries. ${ }^{9}$ It can be established, for instance, that wages in the past twenty-five years have increased more rapidly than the average in those industries in which employment and productivity have increased more rapidly than the average. Similarly, the wages have increased less rapidly than the average in those industries in which employment and productivity have either increased less rapidly than the average or actually declined. Despite all the publicity given to wage changes in the coal and railroad industries, wages in these relatively declining industries have increased less than in manufacturing firms. Between I923 and July, 1946, average hourly earnings in manufacturing increased 109.4 per cent compared to 72.4 per cent for bituminous coal mining and 95.5 per cent for railroads. The simple fact appears to be that the wage structure over a period of time adjusts itself to changes in productivity in such fashion that wage rates increase most where productivity and employment have increased fastest, and wages increase less than the average where productivity and employment have increased less rapidly. However, a substantial part of the increase in productivity, where productivity is increasing fastest, is translated into price declines, increases in profits, and improvements in quality.

(2) The term "productivity" seems to have a fascination and rigor that impels many devotees to regard it as a formula for wage adjustments. The measurement of productivity presents, however, one of the most difficult problems of economic analysis, econometrics, and statistical measurement. ${ }^{10}$ The customary measure of productivity is "output per man-hour," a measure secured by dividing a measure of product in physical units by a measure of man-hour inputs. ${ }^{11}$

In many industries the task of constructing an index of physical production is

- See Alvin.H. Hansen, Wages and Prices: The Basic Issue, N. Y. Times Mag. Jan. 6, 1946, p. 9. ${ }^{20}$ For 2 more comprehensive survey of the statistical problems of measurement, see Nat. BUR. OP Economic Research, Cost Behavior and Price Policy (1943) 142-169.

${ }^{21}$ For a cirrent series, see Productivity Changes Since 1939 (1946) 63 Mo. LAB. Rev. 893. 
formidable, if not impossible. There may be many different products and their proportions in total output, or the "product-mix," may change frequently. While changes in quality and specifications will be particularly important in a job-order business, these factors are present to some extent in almost every case. ${ }^{12}$

(3) Between any two periods output per man-hour may vary as a result of a great many different factors, among which are the following: a change in the level of output, a change in the composition of production, changes in the average effectiveness of plant and equipment-as a result of scrapping obsolete facilities and bring. ing in new ones-increased effort and application on the part of the work-force, a change in the composition of the work-force, improvements in earlier stages of production as in the concerns which supply materials and parts, the substitution of other factors such as increases in wage rates, etc. These circumstances are hardly equally valid bases for an increase in wage rates in a particular plant or company.

In negotiations and public discussion little effort has been made to separate the effects of these factors influencing "productivity" in the sense of output per manhour. The union may argue, on the basis of general knowledge of the industry, that productivity increases which have taken place provide a basis for wage increases. The Steel Workers Organizing Committee, as an illustration, argued in the Little Steel case in 1942 that "workers should receive an equitable share of the proceeds of increasing productive efficiency." 13 In addition to generally available output-perman-hour data the union gave examples of man-hour savings through important technical changes. In a later case ${ }^{14}$ the United Steelworkers of America supported its case by pointing in detail to new capacity, to the abandonment of obsolete facilities, to changes in the quality and composition of the labor force, and to the effects of further integration.

Evidence of changes in productivity is not readily transformed into cents-per-hour wage adjustments. In a number of industries, such as local transit and utilities, wage costs are to some extent a fixed cost, so that changes in output substantially influence output per man-hour. A higher wage rate in some.industries may induce more careful inspection or use of higher-quality materials. Such a change would be reflected in output per man-hour. As has been indicated, these various types of factors affecting output per man-hour are not equally valid grounds for a wage rate adjustment. Not only is the measurement of productivity changes difficult, but their interpretation for relevant wage negotiations is even more ambiguous.

(4) Depending upon the precise meaning given to the productivity argument, the problem of the relation of wage changes to declines in productivity may have to be faced. In the normal case, changes in productivity may be regarded as typically

\footnotetext{
${ }^{22}$ For an instance of the measurement of production in the steel industries, sec Steel Industry, Prices, Profits and Costs (Office of Price Administration, August, 1944) 37-41a. This study is cited in Pantip Murray, Steelworkers Need a \$2.00-A-Day Wage Increase (1946) 60-62.

${ }^{12}$ Brief submitted by the S. W. O. C. to a Panel of the National War Labor Board (1942) 75.

16 Murray, op. cit. supra note 12, at 44-68.
} 
in one direction. There are instances, however, in which performance per average unit of labor input may decline as a result of the exhaustion of a resource, the use of a less skilled labor force on the average, or as the result of less intensive application. Under these circumstances is there an argument for a wage decrease?

\section{Cost-of-Living INDEX}

The change in the cost-of-living index ${ }^{15}$ has been used during some periods as a standard to determine changes in wage rates. The relative emphasis placed on the cost of living by management and labor organizations depends on whether living costs are rising or falling. The attention given to this influence in wage discussions is greatest during periods of pronounced changes in living costs. In a number of collective bargaining situations sliding scales ${ }^{16}$ have been established to adjust wage rates automatically to changes in the cost-of-living index. The more typical case involves using the cost-of-living argument as one factor among many in negotiations or in other forms of wage fixing.

As an absolute principle of wage determination the cost of living has severe limitations:

(I) The cost-of-living index typically contains important components, such as food and rent, whose price movements are not necessarily good barometers of the change in other wage-determining factors. For reasons peculiar to agriculture and housing, these prices may be out of line relative to the general level of prices. If this be the case, there would be serious question as to the propriety of altering the general level of wage rates, or any rate, by the application of the cost-of-living standard. There have been periods, such as the Twenties, in which industrial prosperity has been associated with agricultural depression. To contend that this fact should be binding in industrial wage-rate determination is dubious, just as a temporary rise in the cost-of-living index arising from a disappointing harvest would hardly be regarded as an appropriate basis for an upward revision in wage-rate levels.

The absolute application of the cost-of-living standard would force practically uniform wage-rate adjustments in all cases. (Admittedly, there are minor geographical variations in rates of change in the cost-of-living index.) But there may be occasion for important variations in the rates of change in wages among firms and industries.

(2) Labor organizations have frequently indicated that application of the cost-ofliving principle over any considerable period would result in a stationary real standard of living for wage earners. The gains of productivity in our system have nor-

\footnotetext{
${ }^{15}$ In 1945 the Bureau of Labor Statistics changed the name of its index to "Consumers' Price Index for Moderate-Income Families in Large Cities." This index ". . measures average changes in retail prices of selected goods, rents, and services, weighted by quantities bought by familics of wage earners and moderate-income workers in large cities in 1934-36. The items priced for the index constituted about 70 per cent of the expenditures of city families whose income averaged \$1,524 in 1934-46."

${ }^{16}$ See Z. Clark Dicrinson, Collective Wage Determination (I941) II7-158, esp. I32-135.
} 
mally been translated in part into increases in wages and salaries. The rigid application of the slogan of cost of living would result in a stationary real wage rate.

(3) Mention may be made briefly of the difficulties of measuring the change in the cost of living. These problems have recently received widespread attention. ${ }^{17}$ It is not always clear whether the proponents of the principle in collective bargaining are interested in measuring the price of a constant bundle of goods and services, or whether they are attempting to measure the change in average expenditures. The latter concept includes the effect of changes in income levels, the effects of administering price structure so as to make available particular price lines of commodities, and "forced" substitutions of the type necessitated by wartime conditions.

(4) The application of any cost-of-living principle to wage determination must surmount the difficult problem of an appropriate base period. If wages are to be adjusted to the changes in the cost of living, there must be some starting point. The unions normally would select the period of the last wage change, in cases of increasing cost of living, while employers would emphasize the point that some more representative period of real earnings should be selected. ${ }^{18}$

(5) Automatic adjustment of the general level of wage rates to the cost-of-living index is not always appropriate policy. There may be times of high employment and output in which such a policy would result in cumulative wage and price increases. High employment is always loaded with inflationary dangers, and wage rate adjustments at such periods must be approached with care to avoid unstabilizing consequences.

\section{AвILIty to PAY}

The slogan of "ability to pay" has received particular attention in the course of postwar wage discussions in the public press and before fact-finding bodies. The argument is not new; probably it is as old as collective bargaining. In its simplest form the argument should be looked upon as a mere reflex of a wage demand. A union would not normally make a wage demand without at the same time stating that the demand could be met. There are, no doubt, some exceptions to this view, as in cases involving marginal concerns, but a union cannot make a demand with conviction unless it also implies that the company or industry can afford the wage increase. In much the same way, in the initial stages of bargaining the employer in rejecting the demand almost has to imply as a stratagem that it cannot be afforded. There are situations in which a company rejects a demand admitting that it can afford the requested adjustment, but these are not typical circumstances. On the most elemental plane, consequently, statements regarding ability to pay have been

\footnotetext{
${ }^{17}$ Report of the President's Committee on the Cost of Living (Office of Economic Stabilization, 1945). The various reports by labor and management representatives and by technical experts are appended.

${ }^{18}$ This issue was presented to the National War Labor Board in the Little Steel Case. The union sought to restore in 1942 the level of real wages as achieved on April 1 , 1941, when a general wage increase of to cents an hour was placed in effect. See I WAR LAB. REP. 324, 334-337.
} 
typically mere concomitants or necessary adjuncts to the demand or rejection of the demand.

Any discussion of ability to pay in more serious terms in wage negotiations necessarily raises a host of conceptual and statistical problems regarding the meaning of the phrase in any particular case. Among the more prominent of these problems are the following:

(I) What is the period during which one is concerned with ability to pay? firm may be able to pay a specific increase for a short period, but not for a longer one. A large part of the difficulties in the postwar period arose from the fact that the unions demanded immediate wage adjustments, while the view of many companies in the reconversion industries was that wage adjustments should be postponed until output had been raised to more nearly normal conditions. Here was a conflict concerning in part the period of time to be considered in decisions concerning ability to pay.

(2) How shall one estimate the effect of wage-rate changes on costs? This question involves the problem of labor productivity, which is dependent not alone on the efforts of wage earners but also on the flow of materials and supplies and the effectiveness of management organization. In estimating the effect of wage-rate changes on costs a decision must also be made on the allowance, if any, to be made for the indirect effects of the wage adjustment on materials, prices, purchased parts, and equipment. ${ }^{19}$

(3) The volume of production will no doubt materially affect ability of an enterprise to pay wages. This difficulty concerns not merely the level of production but also the way in which production may be distributed among different types of goods (broadly, the product-mix), particularly among high- and low-profit items.

(4) The character of competition in the markets in which the products must be sold will substantially affect the ability to pay wage increases. These circumstances will influence the extent to which wage adjustments may be translated into price increases and the effect of such adjustments upon volume of output.

(5) The rate of return on investment to which the company is regarded as entitled will create a problem in determining the ability to pay wages. The familiar complications that have arisen in the regulation of public utilities indicate that this is not a problem to be treated lightly. Differing views on rates of return and valuation will significantly influence the content of the ability-to-pay slogan.

(6) The ability to pay wage increases before and after income taxes will vary substantially. Which measure is appropriate? The handling of other tax issues, such as the carry-back adjustments, may present serious problems in defining ability to pay.

Several recent attempts have been made to apply the ordinary multiple-correla-

10 For an illustration, see the discussion in the steel case of 1943-44, Report of the Steel Panel, 19 WAR LAB. REp. 580 (1944). Also see Report of the Emergency Board in the 1938 Railroad Case. 
tion technique to the problem of determining the capacity of enterprises to pay wage increases. ${ }^{20}$ The analysis of General Motors Corporation, for instance, determined the level of profits by these variables: the level of output, average hourly earnings, cost of materials, prices of the finished products sold by the company, and a productivity time trend. By solving for the values of these relationships to profits on the basis of average relationships for the period $1929-4 \mathrm{I}$, it is possible to estimate the level of profits with specified values for output, wage levels, prices, material costs and productivity (a function of time). The effects of wage-rate changes on profits may be estimated under designated conditions regarding prices, material costs, and output.

This type of analysis no doubt warrants further examination. At least it should contribute to a better understanding of the quantitative relations among production, prices, and costs. The method cannot, however, provide any automatic formula for measuring ability to pay. Its proponents have never claimed that it does. The problems summarized and enumerated above are not suddenly dissolved. The level of output for the future contract period remains dubious. There may be grounds to question whether productivity will be above or below levels predicted from any time trend. ${ }^{21}$ The statistical technique does not eliminate these problems; it may present them in different form.

The correlation technique may present its results in the better-known form of a break-even chart, showing the level of output or the percentage of capacity operations at which the enterprise "breaks even." This point will vary with changes in the prices of the products of the firm, the wage rates, and the productivity of the enterprise. This simple device may provide a helpful basis for discussion in collective bargaining over the economic position of the enterprise. What level of output should an enterprise regard as normal for wage-setting purposes? The analysis may help to suggest that temporarily high or low levels of output are not satisfactory standards by which to fix wage rates expected to be maintained over relatively long periods.

As an absolute principle of wage determination ${ }^{22}$ the ability-to-pay principle is widely recognized as having severe. limitations. In such an extreme form it has probably never been proposed. Contrary to popular impression, the United Automobile Workers did not base their wage demand in the General Motors case on ability to pay. The Union's main case was that a 30 per cent increase-without price increases-was necessary to "prevent disastrous retreat from the national objective of adequate purchasing power in the peacetime economy." The Union then attempted

${ }^{30}$ Purchasing Power for Prosperity, The Case of the General Motors Workers for Maintaining TakeHome Pay (Presented by International Union, UAW-CIO G. M. Department, Walter P. Reuther Director, (1945) ) $55-74$.

${ }^{21}$ See General Motors Reply to UAW-CIO, Brief Submitted in Support of Wage Demand for 52 Hours Pay for 40 Hours Work (1945) 14-19.

${ }^{23}$ See F. R. Farrehild, Profits and the Abiutty to Pay (1946). 
to show that the General Motors Corporation could pay such an increase without a price increase. $^{23}$

The general adoption of the principle of determining wage rates absolutely in accordance with ability to pay would result in very unequal wage levels among different firms. It would be incompatible with many union progams for equalization of wage rates among firms in the same industry or locality. The principle would appropriate to wage earners the incentives which the more profitable firms would have to expand production and employment.

Just as unions have stressed that employers have the ability to pay wage increases in good times, so managements have emphasized inability to pay on other occasions. For instance, one of the major headings in the brief of a company resisting a demand for a wage rate increase stated: "The financial condition of the company with revenues at practically the lowest point in twenty years makes it impossible to increase wages already adequate and at the same time maintain the present standard of transportation service, retain the present number of employees, and continue to render unified service."24 The ability-to-pay argument has been employed frequently by companies attempting to make a case for a lower wage scale than other companies in an industry or locality. By virtue of location, machinéry, size, or temporary financial embarrassment, an enterprise may seek to secure special wage treatment on grounds of inability to pay.

There will be wide differences of judgment in any particular situation concerning the net effect of the factors defining and measuring ability to pay wages, differences not only between parties but also within any group of relatively disinterested observers.

\section{Fundamental Problems}

The analysis of the slogans and principles of wage determination summarized in the four preceding sections indicates that there are fundamental limitations to the application of these principles to particular situations. These limitations must be faced with candor.

First, the range of possible wage rates which would follow from the various possible applications of each of the principles would generally be wider than normal variance between the parties in collective bargaining. The alternative meanings and measurements of each one of these standards are so diverse that the principle frequently can provide little help as an authoritative determination of wages. The same point may be made in alternative language: the differences between the parties are simply translated into alternative meanings and measurements of a particular wage slogan or standard. The range of disputed application of any of these principles is

${ }^{28}$ Purchasing Power for Prosperity, cited supra note 20, at I, 21.

"Brief on Behalf of Pittsburgh R. Co., Arbitration between Pittsburgh R. Co. and Div. No. 85, Amalgamated Ass'n. of Street and Electric R. Employees of America (Hearings held from July 16 to August 18, 1934). 
likely to be'much wider than the normal range of disagreement between the parties.

Second, since all wage determination must be considered with reference to a prospective period, conflicting expections as to the future are certain to result in divergent applications of any set of wage principles. The point is not merely that the future in general is uncertain but that uncertainty exists in respect to the magnitude of specific factors-such as output, price, and productivity-vital to present wage determination.

Third, the application of wage slogans or principles is complicated by the fact that the parties frequently have conflicting and divergent basic objectives. These are particularly contentious when the "time horizons" of the parties are markedly different. The company may be interested in remaining in business over the long run while a union may be interested, by virtue of the political problems of leadership, in its position during the next year. Or the union may be interested in maximizing the position of union members during their lifetime without regard to new and younger employees. A further illustration of this basic conflict exists in a situation in which the management of a particular company may be interested in the continuation of its own position over a period of time, while the union may be concerned with the industry more broadly. Such conflicts in basic objectives are certain to yield divergent wage levels.

Fourth, even if any one of these standards could be applied in an unambiguous way, the problem would remain of choosing among these alternative standards or weighting the results they yield. No two of the principles would result in the identical wage-rate change in a specific situation.

These difficulties suggest a pessimistic conclusion as to the contribution which economics can make to the solution of wage disputes. There is no royal road to the application of economics to wage determination. There is no simple formula which may be simply applied to particular cases. The rigor of the classroom diagram blurs in the face of the complexities of collective bargaining when the rigid assumptions of the formal analysis have been removed. In fact there are no "economic" problems in the real world. There may be economic aspects of problems, but the real problems which require decision must be faced as entities. The more frankly and explicitly technical economists admit this fact, the greater the assistance they may eventually give in the solution of practical problems of wage determination in particular cases.

\section{Criteria for the General Level of Wage Rates}

The slogans and clichés used in discussions of the general level of wage rates would require another major paper. Only some of the more prominent issues can be indicated. There is fairly general agreement among economists that the average increase in productivity constitutes the appropriate norm for the long-term movement of the general level of wage rates. ${ }^{25}$ As average productivity increases, the

${ }^{25}$ Alvin H. Hansen, Economic Policy and Full Employment (1947), 152-160. 
level of money wage rates and salaries should rise. The price level as a whole should remain relatively stable. These norms would roughly continue the actual relationships of the past century.

In order for the price level to remain constant, however, industries with greater than the average increases in productivity must decrease prices. In a day of extensively administered prices, these decreases may not be forthcoming. The pricing mechanism may have lost the flexibility requisite to this standard of wage setting. Moreover, the internal requirements of the labor movement may necessitate larger wage-rate increases than are possible under the productivity standard. Intense leadership rivalries may produce greater wage-rate increases, with a consequent rise in the price level. ${ }^{26}$

As a standard for setting the general level of wage rates, no slogan has received greater attention than purchasing power. While the cliché is used in particular cases, a separate section has not been devoted to it in the preceding discussion since no single wage bargain is so extensive as to permit a particular wage change to affect directly and appreciably the purchasing power expended on the products of the firms in negotiation. The standard of purchasing power must refer to the general level of wage rates.

The crudest form of the argument identifies wage-rate and purchasing-power changes. There is no need here to expand on the fact that the relation between changes in wage rates and the aggregate expenditures for consumption and investment in any period is not simple nor direct.

A more sophisticated form of the purchasing-power standard relates to the balance between wage rates and prices. The Nathan Report is cast in these terms. ${ }^{27}$ The level of wage rates is regarded as too low at the existing level of prices to sustain high levels of employment. Decreases in the price level are regarded as unlikely. ". . . Businessmen show no signs of exercising such self-restraint in their natural search for profits as would bring about a decline in prices except in the face of a sharp reduction in demand." 24 The Nathan Report concludes that a substantial increase in the level of wage rates without corresponding price increases is required to sustain purchasing power and high-level employment.

The Nathan Report raises the fundamental question of the standards to be applied in appraising whether the levels of wages and prices are in balance. ${ }^{2 \theta}$ If a lack of balance is determined, the issue must be faced whether wages or prices should be corrected. These questions cannot be answered by rote. Judgment as to appropriate policy must be based not only on the level of profits but also on the structure of wage rates and prices. (The Nathan Report fails to emphasize the necessity for corrections in the structure of prices. Prices for textiles and foods must be reduced.

\footnotetext{
"See John T. Dunlop, American Wage Detcrmination: The Trend and lts Significance, a paper read before the Chamber of Commerce Institute on Wage Determination, Wachington, D. C., January I I, 1947.

27 Robert R. Nattian and Oscar Goss, 1 Satjoval Wagr Policy for 1947 (1946).

${ }^{28}$ Id. at 3 .

20 The analysis of the ability-to-pay standard in Section JV, above, provides a counterpart to this question in the case of a single negotiation.
} 
They are out of line. A general wage-rate increase cannot improve the internal balance of the price structure.) Judgment as to appropriate wage-price policy must also be influenced by the level of interest rates.

An annual appraisal of the economic outlook, such as is provided in the Report of the Council of Economic Advisors, can promote a widespread understanding of the problems to be confronted in particular wage negotiations. A greater economic literacy among the rank and file of union members and business executives can improve the atmosphere in which specific wage conferences take place.

\section{The Contribution of Economic Analysis}

The restraint of the previous sections follows not so much from modesty as from candor. It must not be concluded, however, that the economist has nothing relevant to say in the process of wage determination, whether it be collective bargaining, arbitration, or governmental wage-fixing. Economic analysis can make at least these distinctive contributions to the settlement of wage disputes:

(I) The parties or other wage fixers need to be reminded of the longer-run consequences of any decision. While no simple formula or standard may be available to fix a wage, the possible effects of any decision on the employer and the union involved need to be explored. Regardless of the standards used in setting wage rates or the objectives of the parties, economic analysis calls attention to the channels of effect of any wage decision on output, prices, and employment. It can serve as the conscience of the parties as to many of the less immediate effects of a wage rate decision.

(2) Economic analysis points to the impacts of wage rates in sectors of the economy outside the immediate decision. It is particularly concerned with the effects of wage changes on the total national income and the aggregate level of output and employment. "What is true of a firm or of a particular industry or of a set of industries need not be true of the economy as a whole. To draw attention continually to such relationships between the parts and the whole is probably the most distinctive function of the economist." ${ }^{30}$

The processes of wage-dispute settlement need to develop, as they are developing, specialized personnel within unions, employers' organizations, and public bodies who are skilled in the exercise of judgment in the intricate and complex business of wage determination. A person so skilled may profitably utilize the technical services provided by statisticians, lawyers, economists, actuaries, publicists, industrial engineers, and others; but the primary need is for the mature practitioner to exercise judgment.

Economic analysis purports to deal with one aspect of human behavior. Wagesetting must involve the totality of behavior. Any practitioner must develop the art of applying the tools of the technician in the light of all of the complexities, and frequently the perversities, of human behavior.

\footnotetext{
${ }^{20}$ Lerner, The Relation of Wage Policies and Price Policies. (1939) XXIX AM. Econ. Rev., ProCEEDINGS 158 .
} 